\title{
How the New World Order and Imperialism Challenge Media Studies.
}

\author{
Kaarle Nordenstreng \\ University of Tampere, Finland, kaarle.nordenstreng@uta.fi, \\ http://www.uta.fi/cmt/en/contact/staff/kaarlenordenstreng/index.html
}

\begin{abstract}
This article first reviews the notion of the New World Information and Communication Order (NWICO) and lessons that can be learned from it. It then discusses how to best conceptualize a) imperialism and b) media and cultural imperialism today, mainly based on the works of Christian Fuchs. The paper takes issue with Colin Sparks' article "Media and Cultural Imperialism Reconsidered", published in the Chinese Journal of Communication in 2012. Both Sparks and Fuchs argue that we have to reconsider the concept of cultural and media imperialism, but they do it in fundamentally different ways. The article exposes the problems of a revisionist approach, as taken by Sparks, but it also advocates a radical approach that is analytical and reflective rather than straightforward and actionoriented.
\end{abstract}

Keywords: New World Information and Communication Order, International communication, History of communication research, Critical school, new imperialism.

Acknowledgement: This article was prepared on the invitation of Xiandai Chuanbo (in Chinese "Modern Communication"), the scientific journal of the Communication University of China in Beijing. It was published there in Chinese in the June 2013 issue (No. 203: 64-68) with the title "Lessons Learned from the NWICO Process". It is published here in English with permission of the journal. I want to acknowledge and have much appreciated the comments provided by issue editor Yuezhi Zhao and translator Xu Peixi.

\section{The New World Information and Communication Order (NWICO)}

The concept of a New World Information and Communication Order, known as NWICO, became a leading theme in global media policy debates from the 1970s until the 1990s, covering the period from heights of decolonization to the collapse of Soviet communism. The debates started in diplomatic forums of the developing countries, particularly the Non-Aligned Movement (NAM) in the 1970s, and extended to professional and academic circles so that in the 1980s NWICO was part and parcel of the discourse on the media's role in society and the world at large. By the new millennium, however, it disappeared from the agenda, to be replaced by concepts such as media globalization. In the 2010s, NWICO already belongs to the history of the field of media and communication studies - a history that keeps reemerging under a different aegis.

In brief, the concept was born in an aggressive wave of decolonization spearheaded by the NAM in the first part of the 1970s. It was consolidated during an information war, with a counterattack by the Western powers in the mid-1970s, followed by a diplomatic truce in the late 1970s. Then it was shunned by another Western corporate anti-NWICO offensive in the 1980 s, and finally frozen in the turmoil of the 1990s. Yet its idea carried over to the new millennium, no longer as a pervasive concept but embedded in a number of key issues in global media policy and study.

NWICO is quite a hot chapter in the history of the field. It connects the media, and the study of the media, to the geopolitical struggles between the American-led "West" and the Soviet-led "East", on the one hand, and the industrialized "North" and the developing "South", on the other. NWICO became the buzzword for media controversies in the final period of the Cold War and in the transition to a post-Cold War world. However, NWICO did not only serve 
as a political context to media and their policies at the time. It was also a catalyst for a paradigmatic shift in international communication studies.

I have reviewed the history of NWICO several times since the 1980s (the latest contributions are: Nordenstreng $2011,2012,2013)^{1}$. The narrative is largely the same in other reviews, notably that by Ulla Carlsson (2003). The overall picture of NWICO remains the same in a leading textbook on international communication by Daya Thussu (2006). Another textbook on global communication by Thomas McPhail (2006) includes several passages on NWICO, but it is covered with a Western bias as a scheme for government control of the media. Such a perspective misses the development of NWICO in the 1990s whereby nongovernmental organizations and the so-called civil society at large became the main promoter of NWICO in platforms such as the MacBride Round Table ${ }^{2}$.

In this context it is worth recalling what I wrote in the early 1990s:

In general terms, NWICO should be seen not just as high politics by governments but first and foremost as a project of what is called the citizens' organizations. Media scholars and professionals have their natural place in these constituents of civil society - more natural than among politicians and government bureaucrats.

Parallel to a shift from governments to citizens there is a new emphasis in looking at NWICO as a matter of national rather than international concern. In the beginning - in the 1970s - the causes and remedies were mostly spotted outside the Third World, typically among the Western imperialists. This global view, while still valid to a point, tends to overlook the role of national collaborators in maintaining the undesired structures. As a matter of fact, blaming imperialists is often a politically convenient way to preserve the status quo - not to do anything at home even if a lot could be done, and thus actually to work against NWICO. (Nordenstreng 1992, 40-41)

It is also important to note that at the same time the civil society perspective was extended to international relations - next to globalization - and the concept of "global civil society" emerged as a framework for studies in international communication. As shown in the postscript of a reader on international communication in the 1990s (Nordenstreng and Schiller 1993), three historical shifts can be seen in the evolution of the concept of a state: first there was the feudal state, second the capitalist state and third the civic state, with the cornerstone of this new paradigm being no longer national sovereignty but rather global civil society ( $p$. 463).

In general, NWICO no longer occupies a central place in contemporary media studies and policies, but nevertheless it remains an indispensable chapter in media history as a highlight of the global media debates ${ }^{3}$. For example, in their study on media policy and globalization, Paula Chakravartty and Katharine Sarikakis (2006) name the call for NWICO "the most significant struggle over international communication policy in the Fordist era" (p. 30), while its demands for redistribution of communications resources and cultural sovereignty were swept aside in the post-Fordist era by "a kind of 'reregulation' of neoliberal governance" (p. 36).

Colin Sparks (2007) presents a more cynical view of NWICO in his synthesizing work on globalization, development, and the mass media, where NWICO and the MacBride Commission appear in a chapter on "the failure of the imperialism paradigm" (pp. 105-125). Admittedly, Sparks has a point in placing NWICO in the second cycle of the intellectual history of the field: the first dominant paradigm of propagating modernity was followed in the second stage by the paradigm of cultural and media imperialism as well as the paradigm of participation. After these followed the third paradigm of globalization. But Sparks closes his eyes to the fact that NWICO also included elements of the participatory paradigm as part of civil society's orientation.

\footnotetext{
${ }^{1}$ See also Nordenstreng 1984; UNESCO 1986.

2 A book-size account of the MacBride Round Table is given in Vincent, Nordenstreng and Traber 1999.

${ }^{3}$ See Gerbner, Mowlana and Nordenstreng 1993; Mansell and Nordenstreng 2006; Padovani and Nordenstreng 2005.
} 
Moreover, the paradigm shifts from modernization to imperialism and further to globalization were much more complex than suggested by customary cycles of intellectual history. In this puzzle, NWICO continues to serve not only as historical reference but also as a ground for lessons.

The present article moves forward from reviewing the NWICO history to listing the lessons that this history offers for today's media and communication specialists. A particular aspect discussed is the concept of media imperialism that has often been related to NWICO as a slogan but seldomly examined in depth. Finally, this article reflects on the relationship of the idea of NWICO to the so-called critical school of communication research.

\section{Lessons from the NWICO's History}

There are several lessons which can be learned from the NWICO's history. I suggest the following four as most evident:

First, the NWICO was more focused on politics than on media and communication. The determining factors boosting the concept into such a high status were socioeconomic and geopolitical forces rather than intellectual and moral arguments. In other words, power rather than reason set the rules of debate. The lesson is that however impressive your facts, and however persuasive your arguments, you will not gain recognition in the arena of global debate unless you are backed by significant forces - and respectively opposed by significant forces. The rise of the NWICO in the 1970s was facilitated by a combined force of the socalled Second and Third Worlds of the socialist and developing countries, staged against the First World of Western countries. Likewise, the fall of the NWICO in the 1990s was a consequence of the disintegration of the Second and Third Worlds - the socialist East and the developing South.

The anti-NWICO campaign waged by the Western countries serves as an instructive case of Orwellian double-talk: the NWICO was attacked as a curb on media freedom, whereas in reality the concept was designed to widen and deepen the freedom of information by increasing its balance and diversity on a global scale. For its initiators, NWICO was an idealistic instrument of diplomacy, and Third World dictators did not need it as an excuse for suppressing media. The anti-NWICO campaign was an ideologically apologetic exercise by private media proprietors, and it became effective only because of the extraordinary power with which it was waged. In this sense it is justified to call the campaign a "Big Lie".

The second lesson is that the NWICO was more on debate than on changing media reality. In other words, the significance of the process lay mainly in the debate on media policy rather than in the actual phenomena of communication. The whole history of the NWICO offers little in terms of changing media structures and flows - except, perhaps, "in reverse" with increasing concentration, imbalance, etc. - whereas it offers a lot in terms of conceptual thinking and awareness about the role of the media and their relation to global forces.

To be sure, some media realities have changed toward the NWICO objectives. For example, alternative news and feature agencies have emerged and survived; regional and subregional centres have somewhat diversified the global patterns of one-way flow; and journalists in the North have become more sensitized to appreciate foreign cultures. Thus one cannot cynically conclude that the NWICO did not change media realities at all. It did have some consequences in the media world, but they remained limited compared to the loud and highlevel debate on media policy ranging in political, diplomatic as well as professional circles. Accordingly, the World Summit on the Information Society (WSIS), convened at the United Nations in 2003-2005, can be seen in part as a product of the NWICO, but it was all more about policy debate than media reality.

In general, it is safe to say that the issues raised by the NWICO debate by and large remain valid in the contemporary world. Take the very title of the 1978 Mass Media Declaration of UNESCO "concerning the Contribution of the Mass Media to Strengthening Peace and International Understanding, to the promotion of Human Rights and to Countering Racialism, 
Apartheid and Incitement to War". ${ }^{4}$ All aspects, except apartheid, are still relevant. In point of fact, the question of racism and xenophobia in the media is much more topical today than three decades ago, as shown by the Council of Europe and the European Union which have passed declarations with a less liberal tone than provided by the UNESCO compromise. Ethnic and religious "hate speech" as well as war propaganda are not just words in political resolutions but bitter realities around the world - not only in pockets of war and terrorism but also in the centres of the North.

Likewise, the issue of information sovereignty - a central element of the original call for NWICO - is far from resolved or obsolete in the contemporary world. The difference is only that it is no longer a simple confrontation of the US-led West with the Soviet-led East and the NAM-led South, but today it is a much more complicated trajectory of confrontation within a multipolar world with new constellations such as the rising economies of the BRICS (Brazil, Russia, India, China, South Africa). Similarly, like the world itself, also the scholarly paradigms are more complicated than suggested by a simple division between Western and nonWestern research camps.

The third main lesson deals with the dynamics of the policy debate: the NWICO survived under political pressure the better, the more articulated the idea was. It seems that a global idea is the more forceful and persistent, the more thorough and clear its substance in a public discourse. In other words, conceptual clarity fuels resistance to changing political winds. It is essential, then, that a progressive idea should be articulated not only as a political slogan, but as a resolution, law, or even as a scientific theory. Conceptual clarity contributes to resistance against ideological destabilization, whereas a poorly conceptualized idea can easily be suppressed once the political forces behind it decline. An idea that is grounded in in-depth analysis and is widely known to the general public is quite resilient. For example, environmental issues would have been removed long ago from the public agenda by the strong forces of finance and commerce, if environmentalism were not such a well-articulated field (thanks to Greenpeace, etc.).

The fourth lesson finally brings us to the macro structures of our thinking about media and communication: the NWICO demonstrates the importance of a paradigmatic approach to global communication. The very concept of world order invites a holistic view with a big story and a deep structure going beyond particular aspects of international communication such as the bias of news coverage or the regulation of telecommunications. Although the NWICO's surface has been mainly made up of political and policy discourses, the idea of the NWICO compels one to consider also hidden philosophical paradigms behind the manifest expressions. This is vital and healthy in a field that tends to be overwhelmed by a fascination of novelties and technologies.

After these lessons learned from the NWICO history we shall now turn to the broader issue of imperialism that can be seen as a paradigm behind the concept of NWICO.

\section{The Notion of Imperialism in Media Studies}

The NWICO was part and parcel of the developing countries' drive to emancipate themselves from "structures of imperialist power". Even the President of Finland - a capitalist country pursuing neutrality between East and West - highlighted the structural inequalities in the media field in the 1970s: "Just as within Finland there is a situation in the press described as a bourgeois hegemony, on the international arena there is a state of affairs called communication imperialism" ${ }^{5}$. With critical Western scholars such as Herbert Schiller (1976), the phenomenon became known as media and/or cultural imperialism. However, as the NWICO debate gradually declined towards the end of the 1990s, and by the early 2000s was replaced by perspectives of globalization, including the World Summit on the Information Society (WSIS), also the politically flavoured buzzword "imperialism" disappeared from the debates.

\footnotetext{
${ }^{4}$ http://portal.unesco.org/en/ev.php-URL ID=13176\&URL DO=DO TOPIC\&URL SECTION=201.html

5 President Urho Kekkonen's famous address in Symposium on International Flow of Television Programmes, held in Tampere in 1973, is reproduced in Nordenstreng and Varis (1974, 43-45).
} 
Now in the 2010s the concept of media/cultural imperialism has suddenly reappeared on the scholarly agenda. This comeback is signalled by two authors' academic journal articles: Christian Fuchs ${ }^{6}$ wrote about the new imperialism in general as well as its media dimensions in several journals, such as in the journal Global Media and Communication in 2010. Colin Sparks ${ }^{7}$ published the article "Media and Cultural imperialism Reconsidered" in the Chinese Journal of Communication in 2012.

\subsection{Christian Fuchs on Imperialism}

Fuchs published in 2010 three articles (2010a, b, c) that examine the notion of "new imperialism" used in recent Marxist theories ${ }^{8}$. In Science \& Society (Fuchs 2010a) he regrets the lack of a precise theoretical notion of imperialism and suggests:

This absence can be corrected by connecting the notion of new imperialism to the classical theory of imperialism, as found in Lenin's canonical work. Empirical analysis of data from recent decades shows that Lenin's approach remains broadly correct, and that adaptation of his method to new realities strengthens the theoretical foundation of recent work on global capitalism (Fuchs 2010a, 215).

He reminds of the five characteristics on imperialism in Lenin's theory:

1. The concentration of production and capital developed to such a stage that it creates monopolies which play a decisive role in economic life.

2. The merging of bank capital with industrial capital, and the creation, on the basis of 'finance capital', of a financial oligarchy.

3. The export of capital, which has become extremely important, as distinguished from the export of commodities.

4. The formation of international capitalist monopolies which share the world among themselves.

5. The territorial division of the whole world among the greatest capitalist powers is completed. (Fuchs 2010a, 222).

Fuchs (2010a) presents to each of these dimensions a set of macroeconomic data ${ }^{9}$ and with their support concludes that "contemporary capitalism is an imperialistic capitalism in Lenin's sense, and that Lenin's five characteristics of imperialism can be reformulated for contemporary capitalism" (p. 242). He makes a comparable argument in Critical Sociology (Fuchs $2010 b)$, where one of his conclusions is:

Based on Lenin's notion of imperialism, the results of this article allow the conclusion that contemporary capitalism is a new kind of imperialism. The most significant change in the spatial structure of the world economy in the past 50 years has been the deterioration of North America in the areas of capital exports and commodity exports and the rise of China as an important location for FDI inflows and as an important trading country, especially in exports. Other new qualities of the new imperialism are the decline of the economic importance of the USA that has benefited coun-

\footnotetext{
${ }^{6}$ Austrian social scientist with Marxist orientation who moved in 2010 from the University of Salzburg to Uppsala University in Sweden and in early 2013 to the University of Westminster in the UK.

${ }^{7}$ British media scholar with critical orientation who moved in 2011 from the University of Westminster to Hong Kong Baptist University.

${ }^{8}$ As summarized by Fuchs (2010a, 34), contemporary theorists of imperialism form a continuum where at one end are those who argue that imperialism no longer exists in today's world and that a post-imperialistic empire has emerged (notably Hardt and Negri 2000), while at the other end one finds those for whom contemporary capitalism is as imperialistic as a century ago, appearing just with a new face (notably Harvey 2003). A concise historical overview of the research tradition of cultural/media imperialism is provided in Marko Ampuja's critical examination of globalization theories $(2012,78-83 ; 2010,68-72)$.

${ }^{9} \mathrm{~A}$ full report of the data and analysis is available in a larger research report: Fuchs (2009).
} 
tries such as China, France, Italy, and Spain in certain areas of economic activity, while at the same time there is an unquestioned military hegemony of the USA, as well as the new importance and new methods of financialization. The analysis of contemporary capitalism requires returning to and reloading Lenin for critical globalization studies (p. 864).

The third article was published in Global Media and Communication (Fuchs 2010c) where Fuchs repeats the theoretical and empirical analysis along Lenin's five dimensions of imperialism, this time with a focus on the information economy - testing the role played by the information industries in new imperialism. His conclusion is that they are important but not dominant:

One cannot conclude that the new imperialism is a media imperialism or informational imperialism because this would have to mean that media and information are today the most important features of capital concentration, capital export, world trade and warfare, which clearly is not the case. Media and information do play an important role in new imperialism, but they are subsumed under finance capital and the continued importance of fossil fuel, which is a resource that motivates imperialist warfare. Media are characterized by qualities of imperialism such as concentration and transnationalization, which allows us to speak of the imperialistic character of the media within the new imperialism, but not of the existence of media imperialism. (Fuchs 2010c, 56)

Accordingly, Fuchs (2010c) reminds us that media and communication should be situated in the broader context of new imperialism, without raising them too high in the academic and political agenda - something that often happens among media scholars who by their profession are inspired by notions such as the information society and mediatization. Yet Fuchs is determined to defend the feasibility of imperialism as an adequate notion to describe and understand the overall state of affairs in the contemporary world, including the media world.

In another article, Fuchs (2010d) extends a Marxist analysis of informational capitalism to the Internet, suggesting that the notion of class needs to be expanded beyond capital and labour "to include everybody who creates and recreates spaces of common experience, such as user-generated content on the Internet" (Fuchs 2010d, 179). Accordingly, he elaborates a Marxist class analysis of new media and the "knowledge society", introducing a new approach to knowledge labour and class (Fuchs 2010,, 185-190). Referring to his book on Internet and society (Fuchs 2008) he reminds that "informational capitalism is an antagonistic system that by transnationalization and informatization produces at the same time new potentials of class domination and class struggle", concluding that "the exploitation of unpaid knowledge workers, such as Web 2.0 users, has the potential to be channelled into political demands, such as the demand for a wage for all unpaid knowledge workers, which is equivalent to the demand for the introduction of a universal basic income guarantee" (Fuchs 2010d, $194)^{10}$.

\subsection{Colin Sparks on Imperialism}

The other author singled out here is Colin Sparks (2012). In his recent article in the Hong Kong-based Chinese Journal of Communication he joins a number of other scholars who view media and cultural imperialism as being more or less outdated and even discredited. However, he does not suggest to dismiss the notion but rather to revise it - to advance a

\footnotetext{
${ }^{10}$ This article solicited a critical reading by Adam Arvidsson and Elanor Colleoni (2012), to which Fuchs (2012) immediately responded. These scholarly accounts demonstrate how lively and topical are the contemporary Marxist studies of communication. Indeed, "Marx is Back", as highlighted by the special issue of tripleC in 2012 http://www.triple-c.at/index.php/tripleC/issue/view/25 that was edited by Fuchs and Mosco (2012).
} 
redefined theory of cultural/media imperialism. His starting point is cultural imperialism as presented by Herbert Schiller (1976) against which he lists a number of objections, leading him to conclude: "taken together the evidence against the concept of cultural imperialism advanced by Schiller is simply overwhelming" (Sparks 2012, 286). He then reviews alternative perspectives suggested by the literature as well as world realities on the basis of which he turns to "reframing cultural imperialism" (Sparks 2012, 291-293).

The revision rests on three cornerstones: first, cultural imperialism no longer depends on one centre in the world but there is a competition between different states; second, the competition is between the states of the developed world and not a matter of domination of the developed over the developing world; and third, international cultural exchanges must depend on state power instead of being simple economic transactions. Sparks concludes that "it is possible to advance a viable and coherent concept of cultural imperialism" by investigating "the ways in which state power and cultural power are intertwined in the production and circulation of cultural artefacts" (Sparks 2012, 294). In practice, he foresees several conflicts ahead: rivalry between states in terms of their propaganda efforts and conflicts over the nature of news and journalism, over the regulation of international media flows, over the control of the Internet, over the protection of intellectual property as well as over the nature of popular culture (Sparks 2012, 294-296). Academically, however, he sees that "imperialism, cultural imperialism, and the cultural consequences of imperialism are once again an essential part of the theoretical framework for the study of international communication" (Sparks 2012, 296).

Consequently, Sparks, like Fuchs, flags for imperialism as a paradigm in media studies. However, the angles of these two colleagues are fundamentally different. For Sparks (2012, 290 ) the term imperialism "must be used to describe actions of states, rather than what are essentially private economic activities", whereas for Fuchs imperialism covers all the five dimensions analyzed by Lenin. In light of these, Sparks focuses on only the fifth dimension of Lenin's definition of imperialism. Surely the struggle for hegemony can be political rivalry between states (such as the USA and China, as Sparks observes), but it is also a rivalry between state and non-state organizations (such as USA and AI Qaida), or rivalry between transnational corporations in their competition for profits and political influence.

The lack of economic, financial and corporate dimensions in Sparks' notion of imperialism is striking and has led him to a misleading presentation of other scholars' works. For example, referring to Alex Callincos (2009) and David Harvey (2003), he writes that "it is the existence of competing large, developed, states that is the condition for imperialism" (Sparks 2012, 289), while these authors stress the imperialism of both the state and the market, with capital striving for its own "empire of capital" that tries to commodify everything and to accumulate by dispossession. Regarding Schiller, Sparks misses the revision of his original notion of cultural imperialism that resulted in the concept of "transnational corporate cultural domination"11 - something that makes Schiller's idea compatible with the notion of "commodification of everything", a leading theme of the concept of the new imperialism as elaborated by Harvey and others. It is also interesting to note that Sparks' article does not have a single reference to Fuchs, whereas Fuchs (2010c) has Sparks (2007) in his references ${ }^{12}$.

In any case imperialism in general and media imperialism in particular occupy intellectually a vital place in international media studies. As shown by Ampuja (2012), imperialism is more solid and fruitful an analytical tool than globalization has proved to be. Approaches and paradigms differ, with academic schools of thought clashing, but it is important to keep an open mind in considering the lessons from the NWICO process.

\footnotetext{
11 This revision was made in Schiller (1991) and later elaborated in Schiller (2000).

12 Fuchs' important article (2010c) in Global Media and Communication is also missing from the extensive bibliography of Ampuja's book (2012), showing that Fuchs with his Marxist approach to imperialism has still some way to go to be properly recognized.
} 


\section{The NWICO and the Critical School}

As an excursion into the history of ideas in the field, I conducted soul-searching around the relationship between the NWICO and critical scholarship - two tracks of a historical movement, political and intellectual - in the Festschrift for Dallas W. Smythe (Nordenstreng 1993). I traced four aspects common to both sides:

- A holistic view of the world with communication as an integral part of it, whereby communication and power are inseparable and media are seen as an omnipotent factor in society - for good and bad.

- Equality as a predominant value both within society and between nations, whereby imbalance and domination should be countered and pluralism and equal opportunity guaranteed - not just in principle (as libertarians do) but also in practice (as social liberals do).

- Objective truth as the mission of mass communication, based on epistemological realism (common to both bourgeois and Marxist traditions), whereby it is justified to speak about right and false consciousness and about manipulation by the media.

- A normative approach to reality, where at issue are not only supposedly value-free empirical observations but also ethical and ideological positions.

With such components central to both the political and intellectual tracks of the movement, each growing out of its own roots, it was natural that the two tracks at some point met and blended in a mix where it is difficult to tell where science ends and politics begins. The testimony of my participation in the political NWICO movement, while simultaneously active as a scholar of international communication, serves as a lesson that such a mix may promote both science and politics.

But the history of ideas provides us with another lesson, which is more intriguing: the paradox that politicization beyond a certain level turns from a creative ferment into a repressive paralyzer. An instructive case is UNESCO's approach to communication research and policies, examined in my contribution to the Festschrift for James D. Halloran (Nordenstreng 1994). First, from the late 1960s on, UNESCO approached communication research and policies with a critical paradigm, calling for social relevance rather than methodological sophistication, which in practice led to politicization of research. Then, just when such a policy orientation had gained momentum and the message of critical scholars was taken up by crucial forces in the international community, politics became so pervasive that science was left with no proper breathing space - it became a hostage of over-politicization.

In my reflections on the delicate relationship between the political and intellectual tracks of international communication, I first concede that all social phenomena are political in nature and that it is therefore misguided to suggest that a truly scientific study of social communication could ever be free of political implications. Then I point out that high politics may exert a restrictive influence on the intellectual sphere in two respects:

(1) the political forces interfere directly in intellectual inquiry by institutional moves such as allocating resources in accordance with the prevailing political balance, typically muzzling anti-hegemonic progressive scholarship; and

(2) the political atmosphere indirectly influences scholarship through political conflicts and controversies, dominating the intellectual sphere so that the analytical arsenal may become a mere copy of political power configurations.

The latter syndrome was commonly associated with the Cold War, whereby the East-West conflict was so dominant that it left hardly any intellectual space for other considerations beyond the perpetuation of controversies such as freedom vs. censorship. In both camps the end of the Cold War gave hope for the release of much intellectual potential repressed by political expediency. However, the experience has been otherwise, beginning with the vindictive attitude - even persecution mentality - towards those associated with the old socialist 
regimes, including the very reformers instrumental in bringing them down, and ending up with the sale of mediocre neo-libertarianism to the new free market in Eastern Europe.

My conclusion in the 1993 and 1994 articles was that over-politicization may indeed imperil a sound and creative intellectual movement. In the 1995 article I went on to warn that the media scholar operating in the contiguous no man's land between science and politics should keep a safe distance from both. In other words, I saw the ideal media scholar as a dialogical partner in relation to social practice - in a similar way that an anthropologist approaches his/her object. And I elaborated: if we are to follow the good advice of Karl Marx by not merely philosophizing about the world but by going and changing it, the way to do so today is not to get too much involved in dirty politics.

Such an unorthodox position for a son of the 1960s was based on the historical experience - of the struggles around NWICO and beyond - that media scholars cannot after all make much difference on the barricades of the day, but that their contribution can make a great deal of difference by guiding the intellectual orientation of the real political forces and operations in society. In other words, I had become convinced that it is better to focus on a long-term and indirect influence on the paradigms prevailing in society than on a direct intervention in the policy process.

These reflections, made in the early 1990s, seem to me today, two decades later, still quite valid. The world has changed from a unipolar order - with the USA as the number one country and ideologies converging around neoliberalism - towards a multipolar order with China and other rising powers challenging the traditional Western hegemony. In this situation media scholars continue to be faced with the two tracks - political and intellectual - but both are today more complex than they used to be right after the Cold War. The new world order challenges us more than before both as activists and as academics.

\section{References}

Ampuja, Marko. 2012. Theorizing Globalization: A Critique of the Mediatization of Social Theory. Leiden (The Netherlands) / Boston, MA: Brill. [Earlier version in 2010 as doctoral dissertation The Media and the Academic Globalization Debate. Theoretical Analysis and Critique. Helsinki: University of Helsinki. http://urn.fi/URN:ISBN:978-952-10-6401-2]

Arvidsson, Adam and Eleanor Colleoni. 2012. Value in Informational Capitalism and on the Internet. The Information Society 28 (3): 135-150.

Callincos, Alex. 2009. Imperialism and Global Political Economy. Cambridge: Polity.

Carlsson, Ulla. 2003. The Rise and Fall of NWICO: From a Vision of International Regulation to a Reality of Multilevel Governance. Nordicom Review 24 (2): 31-67. http://www.nordicom.gu.se/common/publ_pdf/32 031-068.pdf

Chakravartty, Paula and Katharine Sarikakis. 2006. Media Policy and Globalization. Edinburgh: Edinburgh University Press.

Fuchs, Christian. 2008. Internet and Society: Social Theory in the Information Age. New York: Routledge.

Fuchs, Christian. 2009. A Contribution to Critical Globalization Studies. Centre for the Critical Study of Global Power and Politics, Working Paper CSGP 09/8. Peterborough: Trent University. http://www.trentu.ca/globalpolitics/documents/Fuchs098.pdf

Fuchs, Christian. 2010a. Critical Globalization Studies: An Empirical and Theoretical Analysis of the New Imperialism. Science \& Society 74 (2): 215-247.

Fuchs, Christian. 2010b. Critical Globalization Studies and the New Imperialism. Critical Sociology 36 (6): 839-867.

Fuchs, Christian. 2010c. New Imperialism: Information and Media Imperialism? Global Media and Communication 6 (1): 33-60.

Fuchs, Christian. 2010d. Labor in information capitalism and on the Internet. The Information Society 26 (3): 179-196.

Fuchs, Christian. 2012. With or Without Max? With or Without Capitalism? A rejoinder to Adam Arvidsson and Eleanor Colleoni. tripleC: Communication, Capitalism \& Critique 10 (2): 633-645. http://www.triple-c.at/index.php/tripleC/article/view/434 
Fuchs, Christian and Vincent Mosco, eds. 2012. Marx is Back - The Importance of Marxist Theory and Research for Critical Communication Studies Today. tripleC: Communication, Capitalism \& Critique 10 (2): 127-632. http://www.triple-c.at/index.php/tripleC/issue/view/25

Gerbner, George, Hamid Mowlana and Kaarle Nordenstreng, eds. 1993. The Global Media Debate: Its Rise, Fall, and Renewal. Norwood, NJ: Ablex.

Hardt, Michael and Antonio Negri. 2000. Empire. Cambridge, MA: Harvard University Press.

Harvey, David. 2003. The New Imperialism. Oxford: Oxford University Press.

Mansell, Robin and Kaarle Nordenstreng. 2006. Great Media and Communication Debates: WSIS and the MacBride Report. Information Technologies and International Development 3 (4): 15-36. http://itidjournal.org/itid/article/view/235/105

McPhail, Thomas. 2006. Global Communication: Theories, Stakeholders, and Trends. 2nd ed. Oxford: Blackwell.

Nordenstreng, Kaarle. 1984. The Mass Media Declaration of UNESCO. Norwood, NJ: Ablex.

Nordenstreng, Kaarle. 1992 The NWICO Movement: A Balance Sheet. In Changing International Order in North-East Asia and Communication Policies, edited by Hyeon-Dew Kang, 33-42. Seoul: NANAM.

Nordenstreng, Kaarle. 1993 New Information Order and Communication Scholarship: Reflections on a Delicate Relationship. In Illuminating the Blindspots: Essays Honoring Dallas W. Smythe, edited by Janet Wasko, Vincent Mosco, and Majid Pendakur, 251-273. Norwood, NJ: Ablex.

Nordenstreng, Kaarle. 1994 The Unesco Expert Panel with the Benefit of Hindsight. Mass Communication Research: On Problems and Policies. In Honor of James D. Halloran, edited by In Cees Hamelink and Olga Linné, 3-19. Norwood, NJ: Ablex.

Nordenstreng, Kaarle. 2011. The New World Information and Communication Order: Testimony of an Actor. In Widerworte. Philosophie Politik Kommunikation. Festschrift für Jörg Becker, edited by Frank Deppe, Wolfgang Meixner and Günter Pallaver, 227-237. Innsbruck: Innsbruck University Press.

http://tampub.uta.fi/bitstream/handle/10024/66230/the_new_world_information_and_communicatio n_order.2011.pdf?sequence $=1$

Nordenstreng, Kaarle. 2012. The History of NWICO and Its Lessons. In From NWICO to WSIS: 30 Years of Communication Geopolitics. Actors and Flows, Structures and Divides, edited by Divina Frau-Meigs, Jérémie Nicey, Michael Palmer, Julia Pohle and Patricio Tupper, 29-40. Bristol / Chicago: Intellect.

Nordenstreng, Kaarle. 2013. The New World Information and Communication Order: An Idea That Refuses to Die. In Media History and the Foundations of Media Studies. Vol. I of The International Encyclopedia of Media Studies, edited by John Nerone, 477-499. Chichester, West Sussex: Blackwell.

Nordenstreng, Kaarle and Herbert I. Schiller, eds. 1993. Beyond National Sovereignty: International Communication in the 1990s. Norwood, NJ: Ablex.

Nordenstreng, Kaarle and Tapio Varis. 1974. Television Traffic - A One-way Street? A Survey and Analysis of the International Flow of Television Programme Material. Reports and Papers on Mass Communication, No. 70. Paris: UNESCO. http://unesdoc.unesco.org/images/0000/000075/007560eo.pdf

Padovani, Claudia and Kaarle Nordenstreng. 2005. From NWICO to WSIS: Another World Information and Communication Order? Global Media and Communication 1 (3): 264-272.

Schiller, Herbert I. 1976. Communication and Cultural Domination. New York: International Arts \& Sciences Books.

Schiller, Herbert I. 1991. Not Yet the Post-imperialist Era. Critical Studies in Mass Communication 8 (1): 13-18.

Schiller, Herbert I. 2000. Living in the Number One Country: Reflections from a Critic of American Empire. New York / London / Sydney / Toronto: Seven Stories Press.

Sparks, Colin. 2007. Globalization, Development and the Mass Media. London: Sage.

Sparks, Colin. 2012. Media and Cultural Imperialism Reconsidered. Chinese Journal of Communication 5 (3): 281-299.

Thussu, Daya. 2006. International Communication: Continuity and Change. 2nd ed. London: Hodder Arnold.

UNESCO. 1986. A Documentary History of a New World Information and Communication Order Seen as an Evolving and Continuous Process 1975-1986. Series on Communication and Society, No. 19. Paris. http://unesdoc.unesco.org/images/0008/000802/080202eb.pdf 
Vincent, Richard, Nordenstreng, Kaarle and Traber, Michael, eds. 1999. Towards Equity in Global Communication: MacBride Update. Cresskill, NJ: Hampton. [New edition forthcoming in 2014.]

\section{About the Author}

Kaarle Nordenstreng

Born in 1941, studied Psychology at the University of Helsinki, PhD in 1969. Worked first as journalist in the Finnish national radio and later as head of research in the Finnish Broadcasting Company. Since 1971: Professor of Journalism and Mass Communication at the University of Tampere. Served in Finnish governmental committees on communication policies, international relations and higher education. Internationally, he served as consultant for UNESCO on communication research and policies (1971-76), as Vice President of the International Association for Mass Communication Research IAMCR (1972-88) and as President to the International Organization of Journalists IOJ (1976-90). He published over 40 books (authored and edited) and over 400 articles (in journals and books). More information is available at:

http://www.uta.fi/cmt/en/contact/staff/kaarlenordenstreng/index.html 